\title{
Hubungan Dukungan Sosial dengan Perilaku Manajemen Diri pada Pasien Hipertensi di Puskesmas Pandak I Bantul DI. Yogyakarta
}

\section{The Correlation Between Social Support and Self-Management Behavior among Patients with Hypertension in Puskesmas Pandak I Bantul Yogyakarta}

\author{
Umi Khomsatun $^{1 *}$, Ike Wuri Winahyu Sari ${ }^{2}$ \\ ${ }^{1}$ Program Studi IImu Keperawatan, Fakultas Kesehatan, Universitas Jenderal Achmad \\ Yani Yogyakarta \\ ${ }^{2}$ Departemen Keperawatan Medikal Bedah, Program Studi IImu Keperawatan, Fakultas \\ Kesehatan, Universitas Jenderal Achmad Yani Yogyakarta
}

\begin{abstract}
Background: Hypertension is a chronic disease which needs good self management. One of the factors influencing self-management behavior is social support. There are still limited number of studies which examine the correlation between social support and self-management behavior in patients with hypertension, especially focusing on certain behaviors such as the adherence on taking medicine, food intake, physical activities, smoking, maintaining the body weight, and avoiding alcohol consumption.

Objective: To identify the correlation between social support and self-management behavior in patient with hypertension located in Puskesmas Pandak I Bantul.

Methods: This research design used a descriptive correlative design with cross-sectional approach. The sample were 47 respondents who were selected using purposive sampling technique. The data collection used questionnaire of Chronic Illness Resources Survey (CIRS) and Hypertension Self-Care Activity Level Effects (H-SCALE) which were valid and reliable. The data was analysed using Pearson Corelation and Spearman Rank Test analysis to identify the relationship of social support to self management behavior in patients with hypertension.

Results: The result showed that the social support had a significant correlation with self-management behavior in the food intake domain $(r=0,336 ; p=0,021)$ and in the domain of body weight management $(r=0,392 ; p=0,006)$. Meanwhile, the social support did not have a significant correlation with selfmanagement behaviour in the domains of the adherence on taking medicine $(p=0,351)$, physical activity $(p=0,974)$, and smoking $(p=0,908)$.

Conclusion: There is a significant correlation between social support and self-management behavior in the domains of food intake and body weight management. Nurses can provide health promotion related to self management as well as the increased of social support in patients with hypertension.
\end{abstract}

Keywords: hypertension, self-management behavior, social support

\begin{abstract}
ABSTRAK
Latar Belakang: Hipertensi merupakan penyakit kronik yang memerlukan manajemen diri yang baik. Salah satu faktor yang memengaruhi perilaku manajemen diri adalah adanya dukungan sosial. Namun, penelitian terkait hubungan dukungan sosial dengan perilaku manajemen diri pada pasien hipertensi dengan menggali aspek tiap domain seperti kepatuhan minum obat, asupan makanan, aktivitas fisik, merokok, menjaga berat badan, dan kepatuhan tidak mengkonsumsi alkohol, masih sangat terbatas.

Tujuan: Penelitian ini bertujuan untuk mengetahui hubungan dukungan sosial dengan perilaku manajemen diri pada pasien hipertensi di Puskesmas Pandak I Bantul.

Metode: Rancangan enelitian ini adalah deskriptif korelatif dengan pendekatan cross sectional. Sebanyak 47 responden dipilih dengan teknik purposive sampling. Pengumpulan data menggunakan kuesioner Chronic IIIness Resources Survey (CIRS) dan Hypertension Self-Care Activity Level Effects (H-SCALE) yang telah valid dan reliabel. Analisis data Uji Pearson Correlation dan Spearman Rank digunakan untuk melihat hubungan dukungan sosial dengan perilaku manajemen diri pada pasien hipertensi.
\end{abstract}

\footnotetext{
Corresponding Author: Umi Khomsatun

Jalan Brawijaya Ring Road Barat, Ambarketawang, Gamping, Sleman, Yogyakarta, 55294

Email: umikhomsatun29@yahoo.com
} 
Hasil: Hasil penelitian menunjukkan bahwa dukungan sosial memiliki hubungan yang signifikan dengan perilaku manajemen diri pada domain asupan makanan $(r=0,336 ; p=0,021)$ dan domain manajemen berat badan $(r=0,392 ; p=0,006)$. Sementara dukungan sosial tidak memiliki hubungan yang signifikan dengan perilaku manajemen diri pada domain kepatuhan minum obat $(p=0,351)$, domain aktivitas fisik $(p=0,974)$, dan domain merokok $(p=0,908)$.

Kesimpulan: Ada hubungan yang bermakna antara dukungan sosial dengan perilaku manajemen diri pada domain asupan makanan dan berat badan. Perawat dapat memberikan promosi kesehatan terkait management diri serta peningkatan dukungan sosial pada pasien hipertensi.

Kata Kunci: dukungan sosial, hipertensi, perilaku manajemen diri

\section{PENDAHULUAN}

Hipertensi merupakan peningkatan tekanan darah secara tidak normal yang berlangsung terus-menerus pada beberapa kali pemeriksaan tekanan darah. Hipertensi disebabkan oleh satu atau beberapa faktor risiko yang tidak berfungsi sebagaimana mestinya dalam mempertahankan tekanan darah secara normal. ${ }^{1}$ Seseorang didiagnosa mengalami hipertensi apabila pengukuran tekanan darah sistolik $>140 \mathrm{mmHg}$ dan diastolik $>90 \mathrm{mmHg}^{2}$ Hipertensi dalam periode waktu yang lama dapat menimbulkan komplikasi, sehingga perlu deteksi dini pada hipertensi dengan melakukan pengukuran tekanan darah secara berkala. ${ }^{3}$

Prevalensi hipertensi semakin lama semakin meningkat, mengikuti perubahan gaya hidup seperti kurangnya aktivitas fisik, merokok, konsumsi alkohol berlebih, obesitas, dan stres psikososial. ${ }^{4}$ American Heart Association (AHA $)^{5}$ menyatakan satu dari tiga orang atau sekitar 65 juta orang di Amerika memiliki tekanan darah tinggi. Sebanyak 28\% atau 59 juta orang penderita hipertensi yang beresiko mengakibatkan kematian sebesar 8 juta orang setiap tahunnya. Prevalensi tersebut disusul oleh Singapura yaitu mencapai 27,3\% dan Malaysia yaitu mencapai 22,2\%. Prevalensi hipertensi di Indonesia dari hasil survai di Asia, menunjukkan bahwa penderita hipertensi mencapai 31,7\% dari total jumlah penduduk usia dewasa. ${ }^{6}$ Prevalensi hipertensi di berbagai provinsi di Indonesia yaitu 35,8\% di Daerah Istimewa Yogyakarta, 30,9\% di Bangka Belitung, 30,8\% di Kalimantan Selatan, 29,6\% di Kalimantan Timur dan 29,4\% di Jawa Barat. Prevalensi Hipertensi di Daerah Istimewa Yogyakarta lebih tinggi dibandingkan dengan angka nasional. ${ }^{7}$

Hipertensi dapat meningkatkan resiko sebesar tujuh kali lebih beresiko terkena stroke, enam kali lebih beresiko terkena serangan gagal jantung kongestif, tiga kali lebih beresiko mengalami serangan jantung, dan penyakit kardiovaskuler lainnya. ${ }^{8}$ Upaya promotif dan preventif pencegahan hipertensi dapat dimulai dari peningkatan kesadaran masyarakat untuk melakukan perubahan pola hidup menjadi lebih sehat. Individu dan masyarakat perlu mempelajari perilaku kesehatan secara tepat, untuk memahami dan memperketat gaya hidup yang benar dan menghindari penyakit. ${ }^{9}$

Hipertensi adalah penyakit kronik, sehingga pasien perlu melakukan pengelolaan diri sendiri (manajemen diri), untuk menurunkan gejala serta risiko komplikasi. ${ }^{10}$ Manajemen diri 
pada hipertensi merupakan kemampuan seseorang dalam menjaga perilaku hidup sehat secara efektif, yang terdiri dari diet dan aktifitas fisik, konsumsi obat yang diresepkan, pemantauan mandiri, dan manajemen stress. ${ }^{11}$

Dukungan sosial merupakan salah satu faktor yang berpengaruh terhadap perilaku manajemen diri. Dukungan sosial menurut Taylor dalam King ${ }^{12}$ merupakan informasi dan umpan balik yang diperoleh dari orang lain sehingga pasien meras dicintai, diperhatikan, dihormati, dan dilibatkan dalam jaringan komunitas, serta pasien berkewajiban memberikan timbal balik. Hal ini sejalan dengan pengertian Sarafino \& Smith ${ }^{13}$ yang menjelaskan bahwa dukungan sosial adalah rasa nyaman, bentuk perhatian dan penghargaan, serta bantuan dalam bentuk lain yang diterima pasien dari orang lain ataupun dari komunitas/ kelompok/jaringan. Hal ini juga diperkuat oleh penelitian Osamor ${ }^{14}$ di Nigeria, bahwa $55 \%$ dukungan sosial sangat berpengaruh terhadap seseorang dalam melakukan manajemen diri, terutama dukungan yang bersumber dari teman-teman dekat, dengan nilai $p<0,001$.

Hasil studi pendahuluan yang dilakukan pada tanggal 22 Mei 2019 di Puskesmas Pandak I melalui mewawancarai perawat penanggung jawab penyakit hipertensi, didapatkan hasil bahwa jumlah pasien hipertensi selama tahun 2018 sebanyak 3.595 pasien. Peneliti juga melakukan survei awal dengan mewawancarai tujuh pasien, yang didapatkan hasil bahwa semua pasien mengatakan telah mendapat dukungan yang baik dalam layanan kesehatan, lingkungan sekitar, organisasi, teman, keluarga, dukungan pribadi, dan media. Pasien juga mengungkapkan adanya dukungan dari keluarga dalam mengontrol kesehatan. Namun, ada satu pasien laki-laki dan perempuan yang merasa kurang mendapatkan dukungan sosial karena faktor kesibukan. Sementara perilaku manajemen diri didapatkan hasil dari tujuh pasien tersebut bahwa semua pasien patuh minum obat dalam satu minggu terakhir, semua pasien tidak mengatur pola makan, tiga pasien patuh dalam manajemen berat badan, enam pasien tidak rutin dalam melakukan aktivitas fisik, dan semua pasien mengatakan tidak merokok dan tidak mengonsumsi alkohol.

Penelitian terkait hubungan dukungan sosial dengan perilaku manajemen diri pada pasien hipertensi dengan menggali aspek tiap domain seperti kepatuhan minum obat, asupan makanan, aktivitas fisik, merokok, menjaga berat badan, dan kepatuhan tidak mengkonsumsi alkohol, masih sangat terbatas. Oleh karena itu penelitian ini penting untuk dilakukan.

Tujuan penelitian ini adalah untuk mengetahui hubungan dukungan sosial dengan perilaku manajemen diri pada pasien hipertensi di Puskesmas Pandak I Bantul, Yogyakarta.

\section{METODE PENELITIAN}

Penelitian ini menggunakan desain korelatif melalui pendekatan cross sectional. Lokasi penelitian di Puskesmas Pandak I Bantul, Yogyakarta. Pengambilan data dilakukan pada tanggal 1 s.d. 8 Juli 2019. Populasi pada penelitian ini yaitu pasien hipertensi di Puskesmas 
Pandak I Bantul, Yogyakarta. Sampel yang digunakan sebanyak 47 responden yang dipilih dengan teknik purposive sampling.

Alat ukur yang digunakan untuk menilai dukungan sosial pada pasien hipertensi yaitu kuesioner Chronic Illness Resources Survey (CIRS) dari penelitian Glasgow et al. ${ }^{15}$ yang terdiri dari 22 pertanyaan menggunakan pilihan jawaban skala Likert dengan pilihan angka $1=$ tidak pernah, $2=$ kadang, $3=$ cukup, $4=$ cukup sering, dan $5=$ sering. Skor berada pada rentang 22110 yang artinya semakin tinggi skor, maka dukungan sosial pasien hipertensi semakin baik. CIRS telah dilakukan uji validitas dengan hasil $r_{\text {hitung }}(0,434-0,661)$ lebih besar dari $r_{\text {tabel }}(0,396)$ dan uji reliabilitas dengan hasil analisis Cronbach's Alpha 0,728. Alat ukur perilaku manajemen diri menggunakan kuesioner Hypertension Self-Care Activity Level Effects (H-SCALE) yang dikembangkan kali pertama pada tahun 2011 oleh Jan Warren-Findlow, dan kembali dilakukan pengembangan serta validasi pada tahun 2013 oleh Jan Warren-Findlow dkk. ${ }^{16}$ Kuesioner $\mathrm{H}$ SCALE memiliki 33 unit pertanyaan, terdiri dari lima domain tentang konsumsi obat-obatan, pola makan, aktivitas fisik, merokok, manajemen berat badan, dan mengonsumsi alkohol. Pada domain konsumsi obat-obatan, skor berada pada rentang 0-21, domain asupan makanan dengan rentang skor 0-52, domain aktivitas fisik rentang skor 0-28, domain merokok rentang skor 0-14, domain manajemen berat badan dengan rentang skor 1-50, domain alkohol dengan rentang skor 0-7. Artinya semakin tinggi skor pada domain kepatuhan minum obat, asupan makanan, aktivitas fisik, dan manajemen berat badan, maka semakin patuh. Semakin rendah skor pada domain merokok dan domain alkohol, maka semakin patuh. Kuesioner ini telah valid dan reliabel menurut penelitian sebelumnya yang dilakukan oleh Wibowo ${ }^{17}$ dengan nilai $r_{\text {hitung }}<0,456$ dan didapatkan hasil Cronbach's Alpha yaitu pada domain kepatuhan pengobatan memiliki nilai Cronbach's alpha 0,744-0,924 dan khusus untuk domain konsumsi alkohol memiliki nilai Cronbach's alpha 0,00.

Data pada penelitian ini dianalisis menggunakan analisis univariat untuk menggambarkan karakteristik responden seperti data jenis kelamin, status pekerjaan, tingkat pendidikan dan tinggal dengan siapa di rumah, yang disajikan dalam bentuk distribusi frekuensi dan persentase. Sementara data usia, lama menderita hipertensi, dukungan sosial, serta perilaku manajemen diri, disajikan dalam mean \pm SD jika data terdistribusi normal dan disajikan menggunakan median, minimum, maksimum jika data tidak terdistribusi normal. Analisis bivariat digunakan untuk mengetahui hubungan dukungan sosial dengan perilaku manajemen diri pada pasien hipertensi, yaitu menggunakan Uji Pearson Correlation untuk data terdistribusi normal dan Uji Spearman Rank untuk data tidak terdistribusi normal. Nilai $p<0,05$ dikatakan signifikan.

Penelitian ini telah mendapatkan persetujuan uji kelayakan etik dari Komite Etik Fakultas

Kesehatan Universitas Jenderal Achmad Yani Yogyakarta dengan Nomor: 
Skep/0166/KEPK/VII/2019 yang dikeluarkan pada tanggal 29 Juli 2019. Semua responden dalam penelitian ini telah menandatangani informed consent.

\section{HASIL}

Karakteristik responden pada penelitian tercantum pada Tabel 1 di bawah ini.

Tabel 1. Karakteristik responden pasien hipertensi $(n=47)$

\begin{tabular}{|c|c|c|c|c|}
\hline Karakteristik Responden & $\begin{array}{c}\text { Frekuensi } \\
\text { (f) }\end{array}$ & $\begin{array}{c}\text { Persentase } \\
(\%)\end{array}$ & Mean \pm SD & $\begin{array}{c}\text { Median } \\
\text { (Min-max) }\end{array}$ \\
\hline Usia & - & & $60,01 \pm 10,88$ & \\
\hline \multicolumn{5}{|l|}{ Jenis kelamin } \\
\hline Laki-laki & 16 & 34,0 & & \\
\hline Perempuan & 31 & 66,0 & & \\
\hline \multicolumn{5}{|l|}{ Status pekerjaan } \\
\hline Tidak bekerja & 18 & 38,3 & & \\
\hline Bekerja & 29 & 61,7 & & \\
\hline \multicolumn{5}{|l|}{ Tingkat pendidikan } \\
\hline SD & 20 & 42,6 & & \\
\hline SMP & 9 & 19,1 & & \\
\hline SMA & 16 & 34,0 & & \\
\hline Perguruan Tinggi & 2 & 4,3 & & \\
\hline \multicolumn{5}{|l|}{ Tinggal dengan siapa di rumah } \\
\hline Suami/istri & 10 & 21,3 & & \\
\hline Anak & 6 & 12,8 & & \\
\hline Keluarga & 5 & 10,6 & & \\
\hline Suami dan anak & 16 & 34,0 & & \\
\hline Istri dan anak & 10 & 21,3 & & \\
\hline Lama menderita hipertensi (tahun) & & & & $4(1-23)$ \\
\hline
\end{tabular}

Dilihat dari Tabel 1, rata-rata responden yang mengalami hipertensi berusia 60,01 $\pm 10,88$ tahun. Mayoritas responden berjenis kelamin perempuan yaitu sebanyak 31 responden $(66,0 \%)$. Sementara itu, untuk status pekerjaan, mayoritas responden bekerja yaitu sebanyak 29 responden $(61,7 \%)$. Tingkat pendidikan responden terbanyak yaitu sekolah dasar (SD) sebanyak 20 responden (42,6\%). Mayoritas responden tinggal di rumah dengan suami dan anak yaitu sebanyak 16 responden (34,0\%). Nilai tengah pada domain lama menderita hipertensi responden yaitu 4 tahun dengan nilai minimum 1 tahun dan maksimum 23 tahun serta nilai rata-rata lama menderita yaitu 5 tahun. Sebagian besar kategori lama menderita hipertensi pada kategori 1-5 tahun sebanyak 35 responden (74,5\%).

Gambaran dukungan sosial pasien hipertensi tercantum pada Tabel 2. Pada Tabel 2 menunjukkan bahwa gambaran dukungan sosial pada pasien hipertensi memiliki rata-rata yaitu $64,21 \pm 1,27$ dengan rentang skor 22-110.

Tabel 2. Gambaran dukungan sosial pasien hipertensi $(n=47)$

\begin{tabular}{|c|c|c|}
\hline Variabel & $\begin{array}{c}\text { Rentang Skor } \\
\text { Dukungan Sosial }\end{array}$ & Mean \pm SD \\
\hline Dukungan Sosial $^{\mathrm{a}}$ & $22-110$ & $64,21 \pm 1,27$ \\
\hline
\end{tabular}

Gambaran perilaku manajemen diri pada pasien hipertensi di Puskesmas Pandak I Bantul tercantum pada Tabel 3 di bawah ini. 
Tabel 3. Gambaran perilaku manajeman diri pada pasien hipertensi $(n=47)$

\begin{tabular}{lccc}
\hline \multicolumn{1}{c}{ Variabel } & $\begin{array}{c}\text { Rentang Skor } \\
\text { Manajemen Diri }\end{array}$ & Mean $\mathbf{\text { SD }}$ & $\begin{array}{c}\text { Median } \\
\text { (Min-Max) }\end{array}$ \\
\hline Kepatuhan Minum Obat & $0-21$ & $20,76 \pm 0,91$ & \\
\hline Asupan Makanan & $0-52$ & $29,29 \pm 1,14$ & $13(1-27)$ \\
\hline Aktivitas Fisik & $0-28$ & - & $0(0-14)$ \\
\hline Merokok & $0-14$ & $42,93 \pm 5,54$ & $0(0-0)$ \\
\hline Manajemen Berat Badan & $1-50$ & & \\
\hline Kepatuhan Tidak Minum Alkohol & $0-7$ & & \\
\hline aDinilai menggunakan Hypertension Self-Care Activity Level Effect (H-SCALE), semakin tinggi skor pada \\
domain kepatuhan minum obat, asupan makanan, aktivitas fisik, dan manajemen berat badan, maka \\
semakin patuh. Sementara, jika semakin rendah skor pada domain merokok dan kepatuhan tidak minum \\
alkohol, maka semakin patuh.
\end{tabular}

Tabel 3 menunjukkan bahwa perilaku manajemen diri pasien hipertensi pada domain kepatuhan minum obat memiliki rata-rata skor 20,76 $\pm 0,91$ (rentang skor 0-21), pada domain asupan makanan memiliki rata-rata skor 29,29 $\pm 1,14$ (rentang skor 0-52). Sementara itu, domain aktivitas fisik memiliki nilai median 13 (rentang skor 0-28), dengan skor terendah 1 dan skor tertinggi 27. Domain merokok memiliki nilai median 0 (rentang skor 0-14), dengan skor terendah 0 dan skor tertinggi 14 . Sementara domain manajemen berat badan memiliki rata-rata skor 42,93 $\pm 5,54$ (rentang skor 1-50). Domain kepatuhan tidak minum alkohol memiliki nilai median 0 (rentang skor 0-7), dengan skor tertinggi 0 .

Hasil analisis hubungan dukungan sosial dengan perilaku manajemen diri pada pasien hipertensi di Puskesmas Pandak I Bantul Yogyakarta disajikan dalam Tabel 4.

Tabel 4. Hubungan dukungan sosial dengan perilaku manajemen diri pada pasien hipertensi $(n=47)$

\begin{tabular}{lcc}
\multicolumn{1}{c}{ Perilaku Manajemen Diri } & \multicolumn{2}{c}{ Dukungan Sosial } \\
\cline { 2 - 3 } & Korelasi $(\boldsymbol{r})$ & 0,623 \\
Kepatuhan Minum obat & 0,074 & $0,021^{*}$ \\
Asupan Makanan & 0,336 & 0,974 \\
Aktivitas Fisik & $-0,005$ & 0,908 \\
Merokok & $-0,017$ & $0,006^{\star *}$ \\
Manajemen Berat Badan & 0,392 &
\end{tabular}

*Signifikan dengan $\mathrm{p}<0,05,{ }^{*}$ Signifikan dengan $\mathrm{p}<0,01$

Pada Tabel 4 menunjukkan bahwa dukungan sosial memiliki hubungan yang signifikan dengan perilaku manajemen diri pada domain asupan makanan $(r=0,336 ; p=0,021)$ dan domain manajemen berat badan $(r=0,392 ; p=0,006)$, sehingga dapat disimpulkan bahwa dukungan sosial memiliki hubungan yang lemah (kurang erat) dengan perilaku manajemen diri pada domain asupan makanan dan manajemen berat badan. Sementara dukungan sosial tidak memiliki hubungan yang signifikan dengan perilaku manajemen diri domain kepatuhan minum obat $(p=0,623)$, domain aktivitas fisik $(p=0,974)$, dan domain merokok $(p=0,908)$. Domain kepatuhan tidak minum alkohol tidak dilakukan analisis karena tidak ada responden yang mengonsumsi alkohol. 


\section{PEMBAHASAN}

Dukungan sosial pada pasien hipertensi memiliki rata-rata 64,21 $\pm 1,27$ dengan rentang skor 22-110. Sejalan dengan penelitian oleh Fajriyah, et al. ${ }^{18}$ yang menunjukkan hasil bahwa sebagian besar dukungan sosial keluarga dalam kategori cukup, dapat disimpulkan bahwa dukungan sosial yang diperoleh pasien hipertensi belum maksimal. Dukungan sosial dari dipengaruhi oleh beragam faktor, oleh karena itu penyelesaian masalah kesehatan juga memerlukan pendekatan dari berbagai aspek. Pencegahan primer penyakit hipertensi melalui upaya promosi mengenai penyebab dari penyakit hipertensi serta peningkatan kesehatan dapat dilakuan untuk mencegah terjadinya hipertensi. ${ }^{18}$ Namun, tidak cukup dengan peningkatan pengetahuan dan kesadaran tentang pola hidup sehat, penyakit, dan faktor risiko, diperlukan juga pendekatan melalui adanya dukungan sosial yang dapat memudahkan, memberikan memotivasi serta memberikan dukungan untuk menerapkan gaya hidup sehat serta kegiatankegiatan yang bersifat promotif dan preventif.

Beda halnya dengan hasil penelitian Yulianti ${ }^{19}$ pada 108 responden yang menunjukkan hasil bahwa dukungan sosial yang didapatkan pasien hipertensi sudah maksimal. Dukungan sosial dapat diperoleh secara alami dari keluarga, teman, tetangga atau dari kelompok/ organisasi. Dukungan sosial menekankan pada perilaku orang lain saat memberikan bantuan, seseorang yang dapat menjangkau sumber dukungan sosial, memiliki kesehatan fisik dan mental yang lebih baik dan mampu beradaptasi dalam menghadapi perubahan. ${ }^{20}$

Perilaku manajemen diri pasien hipertensi pada domain kepatuhan minum obat memiliki rata-rata 20,76 0,91 (rentang skor 0 -21), pada domain asupan makanan memiliki rata-rata skor yaitu 29,29 $\pm 1,14$ dengan (rentang skor 0-52). Sementara itu, domain aktivitas fisik memiliki nilai median 13 (rentang skor 0-28) dengan skor terendah 1 dan skor tertinggi 27. Domain merokok memiliki nilai median 0 (rentang skor 0-14) dengan skor terendah 0 dan skor tertinggi 14. Sementara, domain manajemen berat badan memiliki rata-rata skor $42,93 \pm 5,54$ (rentang skor 1-50). Domain kepatuhan tidak minum alkohol memiliki nilai median 0 (rentang skor 0-7) dengan skor tertinggi 0.

Manajemen diri domain kepatuhan minum obat yang paling banyak dilakukan oleh pasien hipertensi adalah mengonsumsi obat pengontrol tekanan darah dengan jumlah yang sesuai anjuran dokter. Menurut Anderson\&Funnell, ${ }^{21}$ hal tersebut merupakan salah satu faktor terbesar yang memengaruhi kontrol tekanan darah dan merupakan aspek pertama dalam mewujudkan kesembuhan pasien. Sementara, manajemen diri domain kepatuhan minum obat yang paling sedikit dilakukan oleh pasien adalah mengonsumsi obat pengontrol tekanan darah di jam yang sama setiap harinya, hal tersebut biasanya terjadi karena pasien tidak terlalu peduli dengan waktu kapan mereka mengonsumsi obat.

Manajemen diri domain asupan makanan yang paling banyak dilakukan oleh pasien adalah mengonsumsi lebih dari satu porsi sayur-sayuran. Hal ini karena seperti yang telah diketahui, 
manfaat sayuran sangat baik bagi kesehatan terutama untuk mencegah dan mengontrol kejadian hipertensi. Sementara, manajemen diri domain asupan makanan yang paling rendah adalah mengonsumsi kacang polong, kapri, dan melinjo. Modifikasi pola dan jenis konsumsi makanan sehari-hari merupakan perbuhan gaya hidup sehat yang memberikan peran cukup besar dalam mengendalikan tekanan darah. Pola konsumsi makanan yang dianjurkan di antaranya bahan makanan tinggi sayur dan buah, tinggi serat, daging, susu rendah lemak, dan kacang-kacangan, hal ini terdapat dalam penelitian oleh Kumala. ${ }^{22}$

Manajemen diri domain aktivitas fisik paling banyak dikerjakan oleh pasien atau responden adalah melakukan aktivitas fisik keseluruhan yang berdurasi minimal 30 menit. Hal tersebut dilakukan agar otot-otot pasien tidak menjadi tegang, dan hal tersebut juga mampu melancarkan peredaran darah pasien. Sementara manajemen diri pada domain aktivitas fisik yang paling sedikit dikerjakan oleh pasien adalah berlatih angkat beban atau kekuatan. Hal itu terjadi karena tidak semua pasien mampu berolahraga dengan mengangkat beban, hal ini sejalan dengan penelitian yang dilakukan oleh Perlindungan, et al. ${ }^{23}$

Perilaku manajemen diri pada domain merokok yang rendah yaitu pasien hipertensi banyak yang tidak merokok. Hal ini mengindikasikan bahwa pasien sudah memahami untuk selalu menjaga kesehatan sehingga penyakit hipertensi tidak semakin memburuk. Penelitian ini juga sejalan dengan penelitian Lestari dan Isnaini, ${ }^{24}$ bahwa riwayat pasien mayoritas tidak pernah merokok. Hipertensi aalah penyakit kronik, sehingga pasien memiliki tanggungjawab dalam melakukan pengelolaan kesehatan diri, untuk menurunkan gejala serta menurunkan risiko adanya komplikasi.

Perilaku manajemen diri pada domain menjaga berat badan yang paling banyak yaitu pasien hipertensi terbiasa memasak makanan-makanan yang lebih sehat. Hal ini menunjukkan adanya kesadaran pasien hipertensi untuk mengonsumsi makanan yang mampu membuat badan lebih sehat dan tidak membuat penyakit hipertensi yang diderita semakin parah. Menurut Kumala, ${ }^{22}$ pasien hipertensi perlu mengonsumsi buah dan sayuran, susu rendah lemak, bahan makanan tinggi serat, dan daging. Selain itu, nutrien spesifik (contoh: asam lemak tak jenuh omega-3) serta bahan makanan kaya akan mineral dan vitamin, mempunyai peran dalam pencegahan dan penendalian hipertensi. Domain menjaga berat badan yang masih rendah yaitu memperhatikan label makanan ketika berbelanja kebutuhan makanan. Artinya bahwa manajemen diri dalam membeli makanan yang sehat kurang diperhatikan oleh pasien hipertensi, misalnya makanan-makanan instan yang perlu dihindari oleh pasien hipertensi karena biasanya tinggi garam dan banyak mengandung zat kimia.

Hasil penelitian ini menunjukkan bahwa seluruh pasien hipertensi tidak mengonsumsi alkohol. Artinya bahwa pasien sudah menyadari akan dampak buruk jika mengonsumsi alkohol. Konsumsi alkohol tidak hanya buruk bagi kesehatan pasien hipertensi, namun juga bagi orang sehat yang tidak terkena hipertensi. Studi yang dilakukan oleh Elvivin, et al. ${ }^{25}$ menunjukkan 
bahwa orang yang mengkonsumsi alkohol dengan jumlah banyak/sering, terbukti memiliki tekanan darah yang lebih tinggi dibandingkan dengan yang tidak mengkonsumsi atau sedikit mengkonsumsi alkohol.

Dukungan sosial tidak berhubungan dengan perilaku manajemen diri pada domain kepatuhan minum obat. Hasil ini didapatkan karena tidak semua bantuan dari keluarga yang bermaksud baik, dapat diterima dengan baik oleh pasien. Adanya perbedaan persepsi antara anggota keluarga yang memberikan bantuan dengan pasien penerima bantuan, sering kali bantuan yang diberikan keluarga disalahartikan oleh pasien. Selain itu, ketidakpatuhan pasien untuk minum obat juga dapat disebabkan oleh kesibukan anggota keluarga sehingga tidak dapat sepenuhnya mendampingi pasien. ${ }^{26}$ Hasil penelitian ini tidak sejalan dengan penelitian oleh Utami dan Raudatussalamah ${ }^{27}$ yang mengemukakan bahwa semakin tinggi dukungan sosial, baik itu keluarga, teman, tetangga, dan masyarakat lainnya, maka semakin tinggi pula kepatuhan pasien untuk minum obat hipertensi, karena pasien merasa diperhatikan dan ada yang mengawasi.

Dukungan sosial berhubungan secara signifikan dengan perilaku manajemen diri pada domain asupan makanan. Hasil penelitian ini sesuai dengan penelitian oleh Prasetyo ${ }^{28}$ yang menunjukkan ada hubungan positif dan signifikan antara dukungan sosial terutama keluarga dengan asupan makanan pada pasien hipertensi. Menurut Skiner dalam Notoadmojo, ${ }^{29}$ mengungkapkan bahwa stimulus atau rangsangan dari luar dapat memengaruhi perilaku seseorang. Keluarga merupakan salah satu faktor yang dapat memengaruhi perilaku makan pasien. Dukungan sosial yang diberikan oleh keluarga dan kerabat terdekat, mampu meningkatkan asupan makanan pasien hipertensi dalam rangka meningkatkan kesehatan. Hubungan dukungan sosial dengan perilaku manajemen diri pada domain asupan makanan menunjukkan kekuatan hubungan dalam kategori lemah. Hal ini menunjukkan bahwa dukungan yang diberikan oleh orang lain mampu memberikan pengaruh terhadap asupan makanan pasien hipertensi, namun tidak terlalu kuat pengaruhnya. Pasien hipertensi berpersepsi bahwa orang lain kurang memperhatikan pola makan yang diberikan kepada pasien. Hal ini tentu berkaitan dengan dukungan sosial yang diberikan oleh keluarga. Menurut Prasetyo, ${ }^{28}$ anggota keluarga dapat membantu mempersiapkan makanan sehat bagi pasien hipertensi. Hal ini tentu menjadi daya dukung yang sangat berarti bagi pasien hipertensi dalam melakukan manajemen diri yang baik, terutama dalam memperhatikan asupan makanannya.

Dukungan sosial tidak berhubungan dengan perilaku manajemen diri pada domain aktivitas fisik $(p=0,974)$. Artinya bahwa responden yang diberikan dukungan sosial maupun yang tidak, maka tetap tidak memengaruhi aktivitas fisik yang dilakukan oleh pasien hipertensi. Menurut penelitian oleh Widyartha et al. ${ }^{30}$ kurangnya aktivitas fisik merupakan faktor risiko yang secara independen berpengaruh pada terjadinya hipertensi. Aktivitas fisik seperti olahraga selama minimal 30 menit per hari dapat menurunkan tekanan darah sebesar 4-9 
$\mathrm{mmHg}$. Aktivitas fisik atau olahraga sangat memengaruhi terjadinya hipertensi, hal ini berarti orang yang kurang aktivitas fisik akan cenderung mempunyai frekuensi denyut jantung lebih tinggi, sehingga otot jantung harus bekerja lebih keras setiap berkontraksi. Menurut Andria, ${ }^{31}$ makin keras dan makin sering otot jantung memompa, maka makin besar tekanan yang dibebankan pada arteri.

Pada penelitian ini tidak terdapat hubungan antara dukungan sosial dengan status merokok. Artinya bahwa responden yang diberikan dukungan sosial maupun yang tidak, maka tidak memengaruhi status merokok pasien hipertensi. Hipertensi disebabkan oleh beberapa faktor, di antaranya adalah kebiasaan merokok. Merokok dapat memengaruhi tekanan darah serta meningkatkan risiko terjadinya penyakit kardiovaskuler. Merokok dapat menyebabkan hipertensi akibat kandungan zat kimia di dalam tembakau yang dapat mengakibatkan lapisan dalam dinding arteri mengalami kerusakan, sehingga lebih rentan terjadi penumpukan plak (aterosklerosis) pada arteri. Menurut Setyanda, ${ }^{32}$ peningkatan tekanan darah terutama disebabkan oleh nikotin yang menyebabkan penyempitan pembuluh darah serta dapat merangsang kerja saraf simpatis sehingga memacu kerja jantung lebih keras. Hipertensi juga terjadi pada perokok karena peran karbonmonoksida dapat menggantikan oksigen dalam darah sehingga memaksa jantung bekerj lebih keras untuk memenuhi kebutuhan oksigen tubuh.

Dukungan sosial berhubungan secara signifikan dengan perilaku manajemen diri pada domain manajemen berat badan. Hasil penelitian ini sejalan dengan pernyataan Niven dalam Tumenggung ${ }^{33}$ yang menunjukkan berbagai faktor yang dapat memengaruhi kepatuhan pasien dalam melaksanakan manajemen berat badan yaitu pemahaman tentang instruksi, kualitas interaksi, sikap dan kepribadian pasien, serta dukungan sosial terutama pada keluarga. Hasil tersebut menunjukkan bahwa dukungan sosial merupakan salah satu faktor yang mempengaruhi kepatuhan pasien dalam melaksanakan manajemen berat badan. Menurut penelitian Tumenggung, ${ }^{33}$ dukungan sosial merupakan salah satu faktor dengan kontribusi yang cukup besar dan sebagai faktor penguat untuk memengaruhi kepatuhan dalam melaksanakan manajemen berat badan pada pasien hipertensi.

Domain kepatuhan tidak minum alkohol memang tidak dilakukan analisis karena tidak ada responden yang mengonsumsi alkohol. Hal ini artinya responden sudah menyadari bahwa konsumsi alkohol tidak baik bagi kesehatan tubuh, terutama bagi pasien hipertensi. Menurut Sari \& Liana, ${ }^{34}$ mengonsumsi alkohol merupakan salah satu faktor risiko terjadinya hipertensi karena merokok dapat meningkatkan kandungan etanol dalam darah yang mengakibatkan tingginya kadar keasaman darah yang berakibat peningkatkan viskositas darah. Terjadinya peningkatan viskositas darah inilah yang akan menyebabkan peningkatan kerja jantung sehingga terjadi peningkatan tekanan darah. 


\section{KESIMPULAN DAN SARAN}

Dukungan sosial berhubungan dengan perilaku manajemen diri terkait asupan makanan dan manajemen berat badan. Sementara dukungan sosial tidak berhubungan dengan perilaku manajemen diri terkait kepatuhan minum obat, aktivitas fisik, dan merokok.

Hasil penelitian ini diharapkan dapat menjadi rujukan bagi Puskesmas agar lebih meningkatkan keterlibatan keluarga dan tenaga kesehatan di dalam program perawatan maupun pengobatan pasien hipertensi. Dengan adanya dukungan sosial dari keluarga dan tenaga kesehatan, dapat mendorong penderita hipertensi untuk tetap patuh melakukan perawatan diri, sehingga tekanan darah dapat terkontrol dengan baik.

\section{UCAPAN TERIMA KASIH}

Penulis mengucapkan terima kasih kepada responden yang bersedia berpartisipasi dalam penelitian ini. Penulis juga mengucapkan terima kasih kepada Nurhandayani dan Yunita Nur Afif yang telah bersedia menjadi asisten penelitian selama pengambilan data.

\section{DAFTAR PUSTAKA}

1. Wijaya S, Putri M. Keperawatan Medikal Bedah Keperawatan Dewasa Teori dan Contoh Askep. Cetakan I. Yogyakarta: Nuha Medika; 2013.

2. Ardiansyah M. Medikal Bedah untuk Mahasiswa. Cetakan I. Yogyakarta : DIVA press; 2012.

3. Departemen Kesehatan Republik Indonesia. Pedoman Teknis Penemuan dan Tatalaksana Penyakit Hipertensi, Jakarta: Direktorat Pengendalian Penyakit Tidak Menular. Jakarta: Depkes RI; 2013.

4. Departemen Kesehatan Republik Indonesia. Pedoman Teknis Penemuan dan Tatalaksana Penyakit Hipertensi, Jakarta: Direktorat Pengendalian Penyakit Tidak Menular. Jakarta: Depkes RI; 2006.

5. American Heart Association. Heart Disease and Stroke Statistics 2010 Update: A Report From the American Heart Association. USA: AHA; 2010. Available from: http://circ.ahajournals.org/cgi/content/full/121/7/e46

6. Azhari MH.Faktor-faktor yang Berhubungan dengan Kejadian Hipertensi di Puskesmas Makrayu Kecamatan Ilir Barat II Palembang. Aisyah: Jurnal IImu Kesehatan. 2017;2(1):23-30.

7. Riset Kesehatan Dasar. Badan Penelitian dan Pengembangan Kesehatan Kementrian Kesehatan. Jakarta: Direktorat Pengendalian Penyakit Tidak Menular. Jakarta: Riskesdas RI; 2013.

8. Sinuraya RK, Siagian BJ, Taufik A, Destani DP, Puspitasari IM, Lestari K, Diantinil A. Pengukuran Tingkat Pengetahuan tentang Hipertensi di Kota Bandung: Sebuah Studi Pendahuluan. Jurnal Farmasi Klinis Indonesia. 2017;6(4):290-297. doi: 10.15416/ijcp.2017.6.4.290.

9. Miller, M. A., Stoeckel, P. R., Babcock, D. E. 2011. Client Education: Theory and Practice. Sudbury Mass: Jones and Bartlett Publishers. 2011.

10. Mulyati L, Yetti K, Sukmarini L. Analisis Faktor yang Memengaruhi Self Management Behaviour. Jurnal Keperawatan Padjajaran. 2013;1(2).

11. Zhong X, Tanasugar C, Fisher BE, Krudsood S, Nityasuddhi D. Awarness and Practice of Self Management and Influence Factor among Individuals with Type Diabetes Inurban Community Setting in Anhui Province, China. Southeast Asian J Trop Med Public Health. 2011;42(21):184-196.

12. King AL. Psikologi Umum: Sebuah Pandangan Apresiatif. Jakarta: Salemba Humanika; 2010.

13. Sarafino, EP, Smith, TW. Health Psychology Biopsychosocial Interactions. Seventh Edition. Hoboken, NJ: John Wiley and Son, 2012

14. Osamor EP. Social Support and Management of Hypertension in South-West Nigeria. Cardiovascular Journal of Africa. 2015;26(1).

15. Glasgow ER, Deborah JT, Manuel BJ, Lisa AS. The Chronic Illnes Resources Survey: Cross-Validation and Sensitivity to Intervention. Health Education Research. 2005;20(4):402-409.

16. Findlow JW, Basalik DW, Dulin M, Tapp H, Kuhn L. Preliminary Validation of The Hypertension Self-Care Activity Level Effects. The Journal of Clinical Hypertension. 2013;15(9):638-643.

17. Wibowo S. Gambaran Perilaku Manajemen Diri pada Pasien Hipertensi di Wilayah Puskesmas Gamping I. Skripsi. Yogyakarta: Universitas Jenderal Achmad Yani Yogyakarta; 2018.

18. Fajriyah N, Abdullah, Amrullah AJ. Dukungan Sosial Keluarga pada Pasien Hipertensi. Jurnal IImiah Kesehatan. 2016;9(2). ISSN 1978-3167.

19. Yulianti. Gambaran Dukungan Sosial Keluarga dan Kualitas Hidup Lansia dengan Hipertensi di Puskesmas Citangkil Kota Cilegon [Skripsi]. Jakarta: Universitas Islam Negri Syarif Hidayatullah; 2017. 
20. Damanik J, Fangohoy EYA, Robert AR, Gaspersz S, Greene, Gilbert J, Pattiasina, C. Buku Pintar Pekerja Sosial. Jakarta: Gunung Mulia; 2009.

21. Anderson MR, Funnell, MM. Patient Empowerment: Myths and Misconceptions. Patient Educ Couns. 2009;79(3).

22. Kumala M. Peran Diet dalam Pencegahan dan Terapi Hipertensi. Damianus Journal of Medicine. 2014;13(1): 50-61.

23. Perlindungan T, Lukitasari A, Mudatsir. Latihan Isometrik Bermanfaat Menurunkan Tekanan Darah pada Penderita Hipertensi. Jurnal IImu Keperawatan. 2016;4(1):71-81.

24. Lestari GI, Isnaini N. Pengaruh Self Management terhadap Tekanan Darah Lansia yang Mengalami Hipertensi. Indonesia Journal For Health Sciences. 2018;02(01):7-18.

25. Elvivin, Lestari H, Ibrahim K. Analisis Faktor Risiko Kebiasaan Mengonsumsi Garam, Alkohol, Kebiasaan Merokok dan Minum Kopi, terhadap Kejadian Hipertensi pada Nelayan Suku Bajo Pulau Tasipi Kabupaten Muna Barat Tahun 2015. Jurnal IImiah Mahasiswa Kesehatan Masyarakat. 2016;1(3).

26. Nisfani AD. Hubungan Dukungan Keluarga dengan Kepatuhan Diit Hipertensi pada Lanjut Usia di Desa Begajah Kecamatan Sukoharjo Kabupaten Sukoharjo [Skripsi]. Surakarta: Universitas Muhammadiyah Surakarta; 2014.

27. Utami SR, Raudatussalamah. Hubungan Dukungan Sosial Keluarga dengan Kepatuhan Berobat Penderita Hipertensi di Puskesmas Tualang. Jurnal Psikologi. 2016;12(1):91-98.

28. Prasetyo AS. Analisis Faktor-Faktor yang Berhubungan dengan Self Care Management pada Asuhan Keperawatan Pasien Hipertensi di RSUD Kudus [Thesis]. Jakarta: Universitas Indonesia; 2012.

29. Notoatmodjo S. Metodologi Peneltian Kesehatan. Jakarta; Rineka Cipta; 2012.

30. Widyartha J. Putra EA, Ani SL. Riwayat Keluarga, Stres, Aktivitas Fisik Ringan, Obesitas, dan Konsumsi Makanan Asin Berlebih sebagai Faktor Risiko Hipertensi. Public Health and Preventive Medicine Archive. 2016;4(2).

31. Andria KM. Hubungan antara Perilaku Olahraga, Stres, dan Pola Makan dengan Tingkat Hipertensi pada Lanjut Usia Posyandu Lansia Kelurahan Gebang Putih Kecamatan Sukolilo Kota Surabaya. Jurnal Promkes. 2013;1(2):111-117.

32. Setyanda YO, Sulastri D, Lestari Y. Hubungan Merokok dengan Kejadian Hipertensi pada Laki-Laki Usia 3565 Tahun di Kota Padang. Jurnal Kesehatan Andalas. 2015;4(2):434-440.

33. Tumenggung I. Hubungan Dukungan Sosial Keluarga dengan Kepatuahan Diet Pasien Hipertensi di RSUD Toto Kabila Kabupaten Bone Bolango. E-Journal Keperawatan. 2013;(7)1:1-12.

34. Sari RK, Liana. Faktor-Faktor yang Memengaruhi Hipertensi. Jurnal Ilmiah Permas. 2016;6(2);1-10. 